\section{'Puzol': A Facultatively Parthenocarpic Hybrid of Pepino (Solanum muricatum)}

\author{
Jaime Prohens, Miguel Leiva-Brondo, Adrián Rodríguez-Burruezo, \\ and Fernando Nuez \\ Centro de Conservación y Mejora de la Agrodiversidad Valenciana, \\ Universidad Politécnica de Valencia, Camino de Vera 14, 46022 Valencia, Spain
}

Additional index words. cultivar development, new crops, fruit set, yield

Pepino (Solanum muricatum Aiton) is a vegetatively propagated Andean crop that is being introduced as an alternative vegetable crop for protected cultivation (Prohens et al., 1996). The pepino is not an exacting plant and can be grown, with few modifications, with the same techniques used for tomato. Pepino fruit is very versatile and can be eaten at different ripening stages (Sánchez et al., 2000). When the fruit is ripe, it has a golden-yellow ground color and can be used as a fruit for desserts, in fruit salads, or in elaborate dishes with seafood, ham, etc. When the fruit has reached final size, but only has an incipient yellow color, it can be used in the same way as cucumber (Cucumis sativus L.). Its high content in vitamins indicates good prospects for pepino (Nuez and Ruiz, 1996).

A common practice has been to use fruits from pepino cultivars both for salad and dessert uses, depending on their ripening stage. However, fruits of salad cultivars are too low in sugar for use as dessert fruit. On the other hand, pepinos from dessert cultivars may have an inadequate texture or shape for use in salads. Therefore, selection in pepino should be based on the intended use of the fruit. When pepino fruits are to be used as dessert fruit, sweetness is a very important characteristic, and fruits should have a soluble solids content (SSC) higher than 8\% (El-Zeftawi et al., 1986). However, when used unripe in salads, high SSC values are not as important (values between $6 \%$ and $9 \%$ are acceptable), and other characteristics, such as elongate shape (to be cut in slices like cucumber) and crispy texture, are of main relevance in breeding programs.

As a result of a breeding program to obtain a pepino cultivar for use in salads, we have developed a parthenocarpic hybrid cultivar ('Puzol') with a high yield in a wide range of environmental conditions. 'Puzol' (Fig. 1) has elongated, large, and uniform-sized fruits that have a crispy texture and no sour aftertaste, which is often associated with parthenocarpy. Currently, 'Puzol' is being commercially grown in the Spanish Mediterranean area.

This cultivar combines heterosis for vigor and yield characteristics resulting from unrelated parents (Prohens and Nuez, 1999) and facultative parthenocarpy conferred by the

Received for publication 18 Dec. 2000. Accepted for publication 17 July 2001. This contribution was financed by CICYT (AGF 99-0552), CICYT and EU (1FD97-0137) and INIA (OT99-002-C2-2). parthenocarpy gene $P$, which allows fruit set when conditions for pollination are unfavorable. This results in a high and stable yield under a wide range of conditions.

\section{Origin}

'Puzol' is a clonal hybrid obtained in 1994 as a result of a cross between '9-2', a homozygous clone for the parthenocarpy gene $P$ (Prohens et al., 1998), and '6-21', an experimental clone that is a full sib of the cultivar Sweet Round (Fig. 2). The parents '9-2' and '6-21' were initially selected from seeds extracted from New Zealand and Chile fruits, respectively. ' $9-2$ ' has a high yield and its fruits are conical in shape, and presents a sour off-flavor that makes the fruit unpleasant to
Fig. 1. Plant of 'Puzol'. the taste. '6-21' has elongated fruits, with a high SSC and an excellent flavor for a dessert fruit, but a moderate yield.

'Puzol' was initially selected for its high yield among a population of different hybrids obtained between parental plants from different origins. Pepino plants from crosses between unrelated parents are usually heterotic for yield characteristics (Prohens and Nuez, 1999). Due to its highly heterozygous nature, 'Puzol' does not breed true. In the same way, because '9-2' and '6-21' show a certain degree of heterozygosity, the only way to maintain the characteristics of this cultivar is through vegetative propagation, which is the common reproductive practice for this species (Nuez and Ruiz, 1996).

\section{Description}

The 'Puzol' plant is vigorous. The stems are strong, resulting in a semierect growing habit. However, untrained plants expand over the soil, and stems in contact with wet soil will root. Propagation is performed by herbaceous cuttings, which root easily in a wet substrate like vermiculite or peat, or by micropropagation.

Leaves are simple, lanceolate, large (up to $25 \times 7 \mathrm{~cm}$ ), and give a good fruit cover, preventing sunscald. Flowers have white petals with purple stripes, and at anthesis the ovary is more swollen than that of non-parthenocarpic genotypes. Under moderate tem-

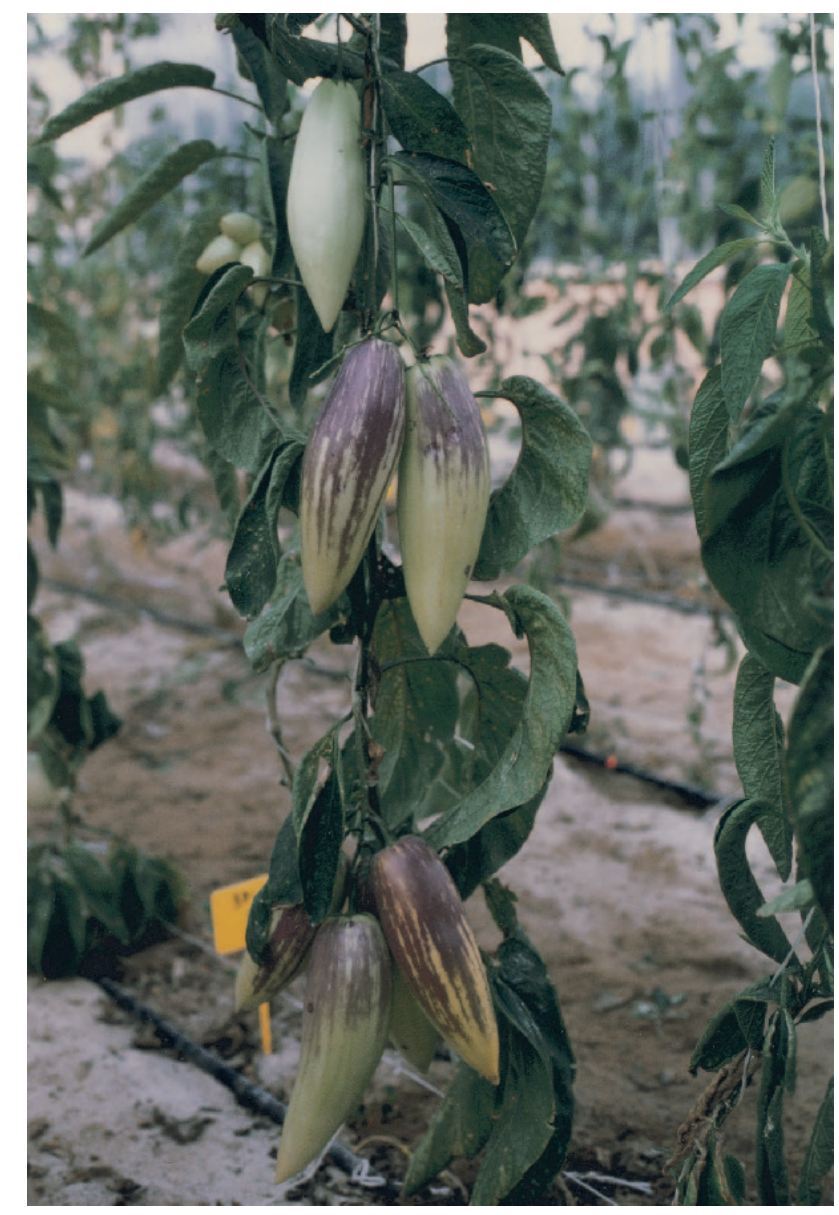


peratures $\left(<25^{\circ} \mathrm{C}\right)$ 'Puzol' has a high pollen fertility, usually higher than $70 \%$. However, at high temperatures $\left(>30^{\circ} \mathrm{C}\right)$ pollen can become completely sterile. This kind of reaction is characteristic of this species (Ercan and Akilli, 1996). Flowering is profuse, with seven to 15 flowers per inflorescence, of which between two and six fruits can set. Due to the facultative parthenocarpy showed by this clone, fruits will set seeded fruits when pollination is successful, which occurs when pollen fertility is high and when flowers are shaken, by wind or insects, or seedless fruits when fertilization does not take place. Due to its facultative parthenocarpy, 'Puzol' can set fruits even when the conditions do not favor pollination (especially when temperatures during fruit set are high), which results in a more stable yield. Percentage of parthenocarpic fruits usually varies from $50 \%$, under conditions that favor pollination (e.g., open-air cultivation in the spring-summer cycle) to $100 \%$ when conditions are unfavorable for pollination (e.g., glasshouse cultivation in the autumn-winter cycle). Fruit quality is not affected by the presence or lack of seeds.

Although differences in temperature between spring-summer and autumn-winter growing cycles used under Mediterranean conditions are important (Prohens et al., 2000), 'Puzol' is well adapted to both cycles. The main performance difference between cycles is that the percentage of parthenocarpic fruits is higher in spring-summer. In order to control the vegetative growth of this cultivar, the vine should be trained with vertical strings in a twoto three-leader system or trellised between double horizontal wires in a hedge-like manner, as is usual with the pepino (Nuez and Ruiz, 1996). In all trials, 'Puzol' had an equivalent or higher yield than other commercial cultivars and the high-yielding but ill-flavored parent '9-2' (Table 1). The other parent clone, '6-21', was not included in trials because it has low yield. In addition, 'Puzol' shows good tolerance to salinity and low susceptibility to red mite (Tetranychus urticae Koch.) infestations, as observed by us in several growers' fields in which other commercial cultivars were grown.

'Puzol' plants present a good fruit set in most trusses, with very uniform sized fruits. They are elongated and reach weights of 200 $400 \mathrm{~g}$, which are appropriate shapes and sizes for their consumption in salads. For this use, fruits have to be harvested when the yellow color of the skin is incipient, and purple stripes begin to appear. Stripes cover between $5 \%$ to $20 \%$ of the fruit surface, depending on exposure of the fruit to the sun. The higher the sun exposure, the more stripes appear. The pulp of the fruit is crispy, juicy, and without a sour aftertaste. Three lots of five ripe and unripe fruits were analyzed for SSC, acidity, and ascorbic acid content as described in Prohens et al. (1999). Results (expressed as mean $\pm \mathrm{SE}$ ) show that fruit composition is quite uniform and that when fruits are in the optimal stage for use in salads (unripe), they present moderate $\operatorname{SSC}(6.6 \% \pm 0.3 \%)$, which is adequate for use in salads. However, in the ripe stage, SSC is

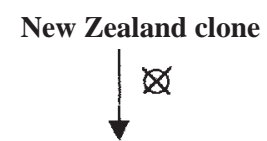

Segregating offspring
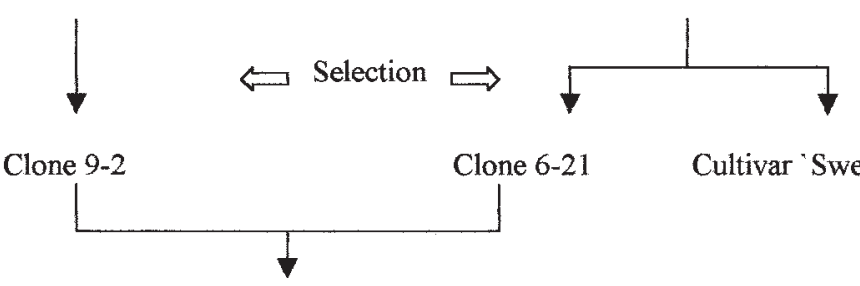

Cultivar 'Sweet Round'

Segregating offspring

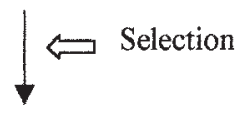

Cultivar 'Puzol'

Fig. 2. Pedigree of 'Puzol'.

Table 1. Yield (t.ha $\left.{ }^{-1}\right)$ of 'Puzol' and other cultivars in Spain in the Mediterranean localities of Valencia, Valencia and Almenara, Castellon.

\begin{tabular}{|c|c|c|c|c|c|c|}
\hline & \multicolumn{3}{|c|}{ Spring-Summer cycle } & \multicolumn{3}{|c|}{ Autumn-Winter cycle } \\
\hline & $\begin{array}{c}\text { Valencia } \\
1998\end{array}$ & $\begin{array}{c}\text { Valencia } \\
1999\end{array}$ & $\begin{array}{c}\text { Almenara } \\
1999\end{array}$ & $\begin{array}{l}\text { Valencia } \\
\text { 1998-99 }\end{array}$ & $\begin{array}{l}\text { Valencia } \\
1999-00\end{array}$ & $\begin{array}{c}\text { Almenara } \\
1999-00\end{array}$ \\
\hline 'Puzol' & $65.6 \mathrm{a}^{\mathrm{z}}$ & $65.6 \mathrm{a}$ & $67.4 \mathrm{a}$ & $48.7 \mathrm{a}$ & $66.6 \mathrm{a}$ & $65.8 \mathrm{a}$ \\
\hline 'Kawi' & --- & $26.6 \mathrm{bc}$ & $39.2 \mathrm{~b}$ & $36.0 \mathrm{~b}$ & --- & --- \\
\hline 'Lima’' & $50.2 \mathrm{bc}$ & $42.5 \mathrm{ab}$ & --- & --- & $58.0 \mathrm{ab}$ & --- \\
\hline 'Otavalo' & $55.9 \mathrm{~b}$ & $55.9 \mathrm{a}$ & --- & $38.2 \mathrm{~b}$ & $44.2 \mathrm{abc}$ & --- \\
\hline 'Quito' & $12.6 \mathrm{~d}$ & $12.6 \mathrm{c}$ & --- & $11.0 \mathrm{c}$ & $32.4 \mathrm{bc}$ & --- \\
\hline 'Sweet Long' & $43.5 \mathrm{c}$ & --- & $42.6 \mathrm{~b}$ & $29.0 \mathrm{~b}$ & $43.5 \mathrm{abc}$ & $38.5 \mathrm{~b}$ \\
\hline 'Sweet Round' & --- & $22.6 \mathrm{bc}$ & $39.5 \mathrm{~b}$ & --- & $24.2 \mathrm{c}$ & $36.2 \mathrm{~b}$ \\
\hline Parent '9-2' & $55.0 \mathrm{~b}$ & $55.0 \mathrm{a}$ & --- & --- & $53.9 \mathrm{ab}$ & --- \\
\hline
\end{tabular}

${ }^{\mathrm{z}}$ Mean values within columns separated by different letters are significantly different $(P<0.05)$ according to the Newman-Keuls test (Bancroft, 1968).

$7.1 \% \pm 0.4 \%$, a low value to be used as dessert fruit (El-Zeftawi et al., 1988). Fruits have low acidity $\left(7.7 \pm 0.3 \mathrm{mmol} \cdot \mathrm{kg}^{-1}\right.$ citric acid) $\mathrm{com}-$ pared with the standard values for this crop (7$20 \mathrm{mmol} \cdot \mathrm{kg}^{-1}$ citric acid) (Prohens et al., 1999), and moderate levels of ascorbic acid content (205 $\pm 9 \mathrm{mg}$ ascorbic acid/kg juice) according to the usual values for this species (200-400 $\mathrm{mg}$ ascorbic acid/kg juice) (Pluda et al., 1993). Ripe fruits of 'Puzol' present an acidity of 7.8 $\pm 0.5 \mathrm{mmol} \cdot \mathrm{kg}^{-1}$ citric acid and an ascorbic acid content of $406 \pm 16 \mathrm{mg} \cdot \mathrm{kg}^{-1}$ juice. Values of these chemical composition characteristics may vary depending on the environment in which plants are raised, but in general they do not suffer dramatic changes with respect to the values presented here. Fruits harvested to be used in salads show a low sensitivity to manipulation and can be preserved at 5 to $10^{\circ}$ for up to 6 weeks.

\section{Availability}

'Puzol' can be obtained through the Centro de Transferencia de Tecnología, Universidad Politécnica de Valencia (CTT, UPV, Camino de Vera 14, 46022 Valencia, España; e-mail: ctt@ctt.upv.es) by a concession agreement. A limited quantity of material for research purposes can be obtained from F.N., UPV, Camino de Vera 14, 46022 Valencia, Spain; e-mail: fnuez@btc.upv.es.

\section{Literature Cited}

Bancroft, T.A. 1968. Topics in intermediate statistical methods. Vol. 1. Iowa State Univ. Press., Ames.

El-Zeftawi, B.M., L. Brohier, L. Dooley, F.H. Goubran, R. Holmes, and B. Scott. 1988. Some maturity indices for tamarillo and pepino fruits. J. Hort. Sci. 63:163-169.

Ercan, N. and M. Akilli. 1996. Reasons for parthenocarpy and the effects of various hormone treatments on fruit set in the pepino (Solanum muricatum Ait.). Scientia Hort. 66:141-147.

Nuez, F. and J.J. Ruiz. 1996. El pepino dulce y su cultivo. FAO Ser. Prod. y Protección Veg. No. 136, Rome.

Pluda, D., H.D. Rabinowitch, and U. Kafkafi. 1993. Pepino dulce (Solanum muricatum Ait.) quality characteristics respond to nitrogen nutrition and salinity. J. Amer. Soc. Hort. Sci. 118:86-91.

Prohens, J. and F. Nuez. 1999. Strategies for breeding a new greenhouse crop, the pepino (Solanum muricatum). Can. J. Plant Sci. 79:299-305.

Prohens, J., J.J. Ruiz, and F. Nuez. 1996. The pepino (Solanum muricatum, Solanaceae): A "new" crop with a history. Econ. Bot. 50:355-368.

Prohens, J., J.J. Ruiz, and F. Nuez. 1998. The inheritance of parthenocarpy and associated traits in the pepino. J. Amer. Soc. Hort. Sci. 123:376-380.

Prohens, J., J.J. Ruiz, and F. Nuez. 1999. Yield, earliness and fruit quality of pepino clones and their hybrids in the autumn-winter cycle. J. Sci. Food Agr. 79:340-346.

Prohens, J., J.J. Ruiz, and F. Nuez. 2000. Growing cycles for a new crop, the pepino, in the Spanish Mediterranean. Acta Hort. 523:53-60.

Sánchez, M., M. Cámara, J. Prohens, J.J. Ruiz, E. Torija, and F. Nuez. 2000. Variation in carbohydrate content during ripening in two clones of pepino. J. Sci. Food Agr. 80:1985-1991. 